\title{
Correction
}

\section{Correction: High Fat Feeding in Mice Is Insufficient to Induce Cardiac Dysfunction and Does Not Exacerbate Heart Failure}

\section{The PLOS ONE Staff}

There is an error in the second sentence of the Methods section. The correct sentence is: Both diets were purchased from Research Diets Inc. HFD (Cat \#:D12492) consists of 20\% protein, 20\% carbohydrate, and $60 \%$ fat.

There is an error in the fifth sentence of the Methods section. The correct sentence is: For long-term HFD feeding, 6-week-old male C57BL/ 6 mice were placed on a HFD $(60 \% \mathrm{cal})$ derived from either lard (Harlan, TD.06414; HFDL) or milk (Harlan, TD.09766; HFDM), or low fat diet (Harlan, TD.06416; LFD) for 30-33 weeks.

\section{Reference}

1. Brainard RE, Watson LJ, DeMartino AM, Brittian KR, Readnower RD, et al. (2013) High Fat Feeding in Mice Is Insufficient to Induce Cardiac Dysfunction and Does Not Exacerbate Heart Failure. PLoS ONE 8(12): e83174. doi:10.1371/journal.pone.0083174
Citation: The PLOS ONE Staff (2014) Correction: High Fat Feeding in Mice Is Insufficient to Induce Cardiac Dysfunction and Does Not Exacerbate Heart Failure. PLoS ONE 9(11): e113944. doi:10.1371/journal.pone.0113944

Published November 12, 2014

Copyright: (๑) 2014 The PLOS ONE Staff. This is an open-access article distributed under the terms of the Creative Commons Attribution License, which permits unrestricted use, distribution, and reproduction in any medium, provided the original author and source are credited. 